\title{
SISTEM PAKAR MENDETEKSI TINDAK PIDANA CYBERCRIME MENGGUNAKAN METODE FORWARD CHAINING BERBASIS WEB DI KOTA BATAM
}

\author{
${ }^{1}$ Anggia Dasa Putri, ${ }^{2}$ Dapit Pratama \\ ${ }^{1}$ Mahasiswa Program Studi Teknik Informatika Universitas Putera Batam \\ ${ }^{2}$ Dosen Program Studi Teknik Informatika Universitas Putera Batam \\ Email : anggiaputri4@gmail.com
}

Submitted: 16-03-2017, Reviewed: 17 -03- 2017, Accepted 18-03-2017

http://dx.doi.org/10.22202/jei.2017.v3i22244

\begin{abstract}
Advances in information technology provides much convenience for human life, but even this progress simultaneously cause a variety of problems that are not easy to find a way out. One of the problems arising from the development of information technology, namely the birth of crimes that refers to activities undertaken in the virtual world using a computer or computer network technology, known as cybercrime (cybercrime). Crime cybercrime common daily life such Decency, Gambling, humiliation or defamation, extortion or threatening, Spreading false news, Abuse, Hacker, Cracker, falsification of data, due to internet users, or lack of awareness about the Law Number 11 Year 2008 Information and Electronic Transaction applicable. Therefore, this study aims to develop an expert system using programming language PHP (Hypertext Preprocessor) and MySQL database-based web using a forward chaining method to make it easier, knowing, and assist in taking an answer or conclusion of cases and sanctions crime cyberspace (cybercrime) based on Law No. 11 of 2008 on Information and Electronic Transactions applicable.
\end{abstract}

Keywords: Expert System, Law No. 11 of 2008 on Information and Electronic Transactions, Crime Cybercrime, Forward Chaining

\section{I.PENDAHULUAN}

\section{Latar Belakang Masalah}

Perkembangan ilmu pengetahuan dan teknologi informasi mengalami pertumbuhan yang sangat pesat memberikan dampak positif bagi umat manusia. Salah satu perkembangan teknologi yang sampai saat ini terus berkembang yaitu internet. Secara langsung mempengaruhi kebutuhan pokok akan informasi dalam kehidupan manusia saat ini karena semua informasi sangat mudah didapat dalam berbagai aspek kehidupan manusia.Perkembangan di bidang ilmu pengetahuan dan teknologi informasi senantiasa diikuti dengan adanya dampak baik secara langsung maupun tidak. Kemajuan teknologi informasi, masyarakat memiliki ruang gerak yang lebih luas. Aktifitas manusia yang semula bersifat nasional telah berubah menjadi internasional, peristiwa yang terjadi di suatu negara dalam hitungan detik sudah dapat diketahui oleh penduduk belahan dunia lainnya.

Kemajuan ilmu pengetahuan dan teknologi informasi memberikan banyak kemudahan bagi kehidupan manusia, tetapi kemajuan inipun secara bersamaan menimbulkan berbagai permasalahan yang tidak mudah ditemukan jalan keluarnya. 
Salah satu masalah yang muncul akibat perkembangan teknologi informasi adalah lahirnya kejahatan-kejahatan yang sifatnya baru khususnya yang mempergunakan internet sebagai alat bantu nya yang dikenal dengan kejahatan dunia maya (Cybercrime).

Cybercrime di Indonesia terjadi sejak 1983, terutama di bidang perbankan. Dalam tahun-tahun berikutnya sampai saat ini, di Indonesia banyak terjadi cybercrime, misalnya pembajakan program komputer, cracking, penggunaan kartu kredit pihak lain secara tidak sah (carding), pembobolan bank (banking fraud), pornografi, termasuk kejahatan terhadap nama domain (domain name). Selain itu, kasus kejahatan lain yang menggunakan komputer di Indonesia antara lain penyelundupan gambar-gambar porno melalui internet (cyber smuggling), pagejacking (moustrapping), spam (junk mail),

cybersquatting,typosquatting. Sedangkan kasus kejahatan terhadap sistem atau jaringan komputer antara lain cracking, defacing, denial of service attack (Dos), distributed denial of service attack (Ddos), penyebaran virus (worm), dan pemasangan logic bomb (Widodo, 2009:29).

Menurut Widodo (2009) Kejahatan dunia maya (Cybercrime) adalah kejahatan yang dilakukan oleh seseorang atau sekelompok orang atau korporasi dengan cara menggunakan atau dengan sasaran komputer atau sistem komputer atau jaringan komputer. Kejahatan ini terjadi pada dunia maya sehingga mempunyai karakteristik yang berbeda dengan kejahatan tradisional. Karakteristik pelaku cybercrime sangat unik, meskipun hukum pidana konvensional sebagaimana yang berlaku di indonesia dapat digunakan hakim sebagai dasar hukum untuk mengadili pelaku cybercrime, tetapi dalam praktik banyak sekali keterbatasannya, baik dari sisi unsur tindak pidana maupun pertanggungjawaban pidananya. Akibatnya, banyak pelaku yang lolos dari jeratan hukum, atau kalaupun dijatuhi pidana. Berdasarkan hasil penelitian penulis semua pelaku dijatuhi pidana penjara dalam tataran filosofis, teoritis, normatif, maupun empiris berdasarkan Undang-undang Republik Indonesia Nomor 11 Tahun 2008 tentang Informasi dan Transaksi Elektronik.

\section{Rumusan Masalah}

Berdasarkan permasalahan dari latar belakang di atas maka peneliti dapat merumuskan masalah sebagai berikut:(1) Bagaimana sistem pakar mendeteksi kasuskasus serta menentukan sanksi tindak pidanacybercrimeberdasarkanUndangundang Republik Indonesia Nomor 11 tahun 2008 tentang Informasi dan Transaksi Elektronik yang berlaku ?(2)Bagaimana sistem pakar mempermudah dan membantu dalam mengambil suatu jawaban atau kesimpulan tentang kasus-kasus cybercrime berdasarkanUndang-undang Republik Indonesia Nomor 11 tahun 2008 tentang Informasi dan Transaksi Elektronik yang berlaku?

\section{Tujuan Penelitian}

Penelitian ini bertujuan sebagai berikut: (1) Membangun Sistem Pakar agar penguna internet atau dunia maya tentang dampak negatif bila melakukan suatu kejahatan dunia maya (cybercrime). (2) Membangun Sistem Pakardapat mempermudah dan membantudalam mengambil suatu jawaban atau kesimpulan tentang kasus-kasus dan sanksi kejahatan dunia maya (cybercrime) berdasarkan Undang-undang Republik Indonesia Nomor 11 Tahun 2008 tentang Informasi dan Transaksi Elektronik.

\section{Manfaat Penelitian}

Penelitian ini bermanfaat sebagai berikut: (1) Aspek Teoritis Untuk mengetahui mengenai Sistem pakar menggunakan Metode Forward Chaining dan penggunaannya. (2) Aspek Praktis Memberikan kemudahan dan pengetahuan kepadapenguna internet atau dunia 
mayadalam mendeteksi serta menentukan sanksi tindak pidana kejahatan dunia maya (cybercrime) melalui ciri-ciri dari kasuskasus berdasarkan Undang-undang Republik Indonesia Nomor 11 Tahun 2008 Tentang Informasi dan Transaksi Elektronik.

\section{II.LANDASAN TEORI Kecerdasan Buatan (Artificial Intelligence)}

Kecerdasan Buatan

"Artificial Intelligence" pertama kali dikemukakan pada tahun 1956 di konferensi Darthmouth. Selama bertahun-tahun para filsuf berusaha mempelajari kecerdasan buatan yang dimiliki manusia. Dari pemikiran tersebut lahirlah AI sebagai cabang ilmu yang berusaha mempelajari dan meniru kecerdasan manusia. Sejak saat itu para peneliti mulai memikirkan perkembangan AI sehingga teori-teori dan prinsipprinsipnya berkembang terus hingga sekarang (Sutojo, dkk 2011:3)

Kecerdasan buatan berasal dari bahasa inggris "Artificial Intelligence" atau disingkat AI yaitu intelligence adalah kata sifat yang berarti cerdas, sedangkan artificial artinya buatan. Kecerdasan buatan yang dimaksud disini merujuk pada mesin yang mampu berfikir, menimbang tindakan yang akan diambil, dan mampu mengambil keputusan seperti yang dilakukan oleh manusia (Sutojo, dkk 2011:3).

\section{Sistem Pakar}

Sistem pakar merupakan cabang dari Artificial Intelligence(AI) yang cukup tua karena sistem ini mulai dikembangkan pada pertengahan 1960. Sistem pakar yang muncul pertama kali adalah Generalpurpose problem solver (GPS) yang dikembangkan oleh Newel dan Simon. Sampai saat ini sudah banyak sistem pakar yang dibuat, seperti MYCIN untuk diagnosis penyakit, DENDRAL untuk mengidentifikasi struktur molekul campuran yang tak dikenal, XCON dan XSEL untuk membangun konfigurasi sistem komputer besar, SOPHIE untuk analisis sirkuit elektronik, Prospector digunakan dibidang geologi untuk membantu mencari dan menemukan deposit, FOLIO digunakan untuk membantu memberikan keputusan bagi seorang manager dalam stok dan inventasi, DELTA dipakai untuk pemeliharaan lokomotif listrik diesel dan sebagainya (Sutojo, dkk 2011:159-160).

Sistem pakar adalah sebuah sistem yang menggunakan pengetahuan manusia di mana pengetahuan tersebut dimasukkan ke dalam sebuah komputer dan kemudian digunakan untuk menyelesaikan masalahmasalah yang biasanya membutuhkan kepakaran atau keahlian manusia.

\section{Penalaran maju (Forward Chaining)}

Runut maju (Forward Chaning) merupakan proses perunutan yang dimulai dengan menampilkan kumpulan data atau fakta yang menyakinkan menuju konklusi akhir. Runut maju bisa juga disebut sebagai penalaran forward (Forward Reasoning) atau pencarian yang dimotori data (data driven search). Jadi dimulai dari premispremis atau informasi masukan (IF) dahulu kemudian menuju konklusi atau derived information (Then) atau dapat dimodelkan sebagai berikut:

\section{IF (Informasi Masukan) Then (Konklusi)}

Informasi masukan dapat berupa data, bukti, temuan, atau pengamatan. Sedangkan konklusi dapat berupa tujuan, hipotesa, penjelasan, atau diagnosa. Sehingga jalannya penalaran runut maju dapat dimulai dari data menuju tujuan, dari bukti menuju hipotesa, dari temuan menuju penjelasan, atau dari pengamatan menuju diagnosa.

Untuk memahami cara kerja runut maju (forward chaining), perhatikan contoh sebagai berikut: (1) IF lampu 1 dinyalakan (2) AND lampu 1 tidak menyala (3) ANDlampu 1 dihubungkan dengan sekering 
(4) AND sekering masih utuh (5) THEN Lampu 1 rusak.

Secara sederhana runut maju (forward chaining) diterangkan sebagai berikut, untuk kaidah diatas, agar sistem pakar mencapai konklusi, harus disuplay terlebih dahulu fakta lampu 1 mati, lampu 1 dihubungkan dengan sekering, dan sekering masih utuh, baru sistem bisa mengeluarkan konklusi bahwa lampu 1 rusak (Hartati dan Iswanti, 2008:45-46).

\section{Pengertian Hukum Pidana}

Prasetyo (2010:4) ada beberapa pengertian hukum pidana menurut para ahli sebagai berikut: (1) Mezger: Hukum pidana adalah aturan hukum yang mengikatkan pada suatu perbuatan yang memenuhi syarat tertentu suatu akibat yang berupa pidana. (2) Lemaire: Hukum pidana itu terdiri dari norma-norma yang berisi keharusan dan larangan yang oleh pembentuk undangundang dikaitkan dengan sanksi berupa pemidanaan, yaitu suatu penderita khusus. (3) Pompe: Hukum pidana merupakan keseluruhan peraturan yang bersifat umum yang isinya adalah larangan dan keharusan terhadap pelanggarannya. (4) Algra Janssen: Hukum pidana adalah alat yang digunakan oleh penguasa (hakim) untuk memperingati mereka yang telah melakukan suatu perbuatan yang tidak dibenarkan. (5) Muljatno: Hukum pidana adalah bagian daripada keseluruhan hukum yang berlaku disuatu Negara.

Prasetyo (2010:13) mengemukakan bahwa tujuan hukum pidana ialah antara lain: (1) Untuk menakut-nakuti setiap orang jangan sampai melakukan perbuatan yang tidak baik (aliran klasik). (2) untuk mendidik orang yang pernah melakukan perbuatan tidak baik menjadi baik dan dapat diterima kembali dilingkungan kehidupannya (aliran modern).

\section{Kejahatan dunia maya (Cybercrime)}

Kejahatan dunia maya (Cybercrime) adalah kejahatan yang dilakukan oleh seseorang atau sekelompok orang atau korporasi dengan cara menggunakan atau dengan sasaran komputer atau sistem komputer atau jaringan komputer. Perbuatan yang dilarang mengenai Tindak pidana kejahatan dunia maya (cybercrime) diatur dalam Pasal 27 sampai dengan Pasal 37 berdasarkan Undang-Undang Republik Indonesia Nomor 11 Tahun 2008 Tentang Informasi dan Transaksi Elektronik sebagai berikut: (1) KejahatanAsusila (2) Kejahatan Perjudian (3) Kejahatan Penghinaan (4) Kejahatan Pemerasan (5) Kejahatan Berita Bohong dan Menyesatkan (6) Kejahatan Berita Kebencian dan Permusuhan (7) Kejahatan Ancaman Kekerasan dan Menakuti-nakuti (8) Kejahatan Akses Komputer Orang Tanpa Izin (9) Kejahatan Cracking (10) Kejahatan Penyadapan, Perubahan, Penghilangan, Pemindahan dan Perusakan Informasi (11) Kejahatan Membuat Sistem Orang Lain Tidak Bekerja (Virus, DOS) (12) Kejahatan Pemalsuan Data

\section{PHP (Hypertext Preprocessor)}

PHP(Hypertext Preprocessor) adalah suatu bahasa scripting khususnya digunakan untuk web development. Karena sifatnya yang server side scripting, maka untuk menjalankan PHP harus menggunakan web server.

PHP juga dapat diintegrasikan dengan HTML, Javascript, Jquery, Ajax. Namun, pada umumnya PHP lebih banyak digunakan bersamaan file bertipe HTML dengan menggunakan PHP anda bisa membuat website powerful yang dinamis dengan disertai manajemen databasenya. Selain itu juga penggunaan PHP yang sebagian besar dapat jalan di banyak platfrom, menjadi salah satu alasan kenapa anda harus menguasai PHP untuk menjadi web development yang hebat (Hidayatullah dan Kawistara, 2015: 231)

Dengan demikian kode program yang ditulis dalam PHPtidak akan terlihat oleh user sehingga keamanan halaman web lebih 
terjamin. PHPdirancang untuk membuat halaman web yang dinamis, yaitu halaman web yang dapat membentuk suatu tampilan berdasarkan permintaan terkini, seperti menampilkan isi basis data ke halaman web.

Kelebihan yang dimiliki PHP, sebagai berikut (Hidayatullah dan Kawistara, 2015: 234237): (1) PHP berbasis server side scripting (2) Command line scripting pada PHP (3) PHP dapat membuat aplikasi desktop (4) Digunakan untuk berbagai macam plaffrom OS (5)

Mendukung berbagai macam web server (6) Object oriented pemograming atau procedural (7) Outpot file PHP pada XHMTL, HTML dan XML (8) Mendukung banyak RDMS

(database) (9) Mendukung banyak komunikasi (10) Pengelohan teks yang sangat baik.

\section{Database MySQL}

MySQL merupakan salah satu database kelas dunia yang sangat cocok bila dipadukan dengan bahasa pemrograman PHP. MySQL bekerja menggunakan bahasa SQL (Structure Query Laguage) yang merupakan bahasa standar yang digunakan untuk manipulasi database Menurut Saputra (2012:77).

MySQLdikembangkan

oleh perusahaan swedia bernama MySQLAB yang pada saat ini bernama Tcx DataKonsult AB sekitar tahun 1994-1995, namun cikal bakal kodenya sudah ada sejak tahun 1979. Awalnya Tcx merupakan perusahaan pengembang software dan konsultan database, dan saat ini MySQLsudah diambil alih oleh Oracle Corp.

Pada umumnya perintah yang paling sering digunakan dalam MySQL adalah Select (Mengambil), Insert (Menambah), Update (Mengubah), dan Delete (Menghapus). Selain itu, SQL juga menyediakan perintah untuk membuat database, field, ataupun index untuk menambah atau menghapus data.

\section{XАMPP}

Xатpp merupakan kompilasi dari beberapa program. Fungsinya adalah sebagai server yang berdiri sendiri(localhost) yang terdiri atas program Apache HTTP Server, MySQL database dan penerjemah bahasa yang ditulis dengan bahasa pemrograman PHP dan Perl. Nama Xampp merupakan singkatan dari X (empat sistem operasi apapun), Apache, MySQL, PHP dan Perl. Program ini tersedia dalam GNU General Public License dan bebas. Xampp merupakan webserver yang mudah digunakan yang dapat melayani tampilan halaman web yang dinamis.

Bagian penting XAMPP yang biasa digunakan pada umumnya: (1) XAMPP Control Panel Aplication berfungsi mengelola layanan (service) XAMPP. Seperti mengaktifkan layanan (start) dan menghentikan (stop) layanan. (2) htdoc adalah folder tempat meletakkan berkasberkas yang akan dijalankan. Di Windows, folder ini berada di C:/xampp (3) phpMyAdmin merupakan bagian untuk mengelola database

\section{Adobe Dreamweaver}

Adobe dramweaver merupakan program penyunting halaman webadobe system, yang dulu dikenal sebagai MacromediaDreamweaver keluaran macromedia. Program ini banyak digunakan oleh penggembang web karena fitu-fiturnya yang menarik dan kemudahan penggunaanya. (Maudi Meiska Firstiar, dkk, 2014:102)

Dreamweaver memiliki fitur dari browser yang terintegrasi untuk melihat halaman web yang dikembangkan di jendela pratinjau program sendiri agar konten memungkinkan untuk terbuka di web browser yang sedang telah terinstall. 


\section{III.METODE PENELITIAN Desain Penelitian}

Penelitian ini menggunakan desain penelitian dengan beberapa tahap proses penelitian seperti yang terlihat pada gambar 1.

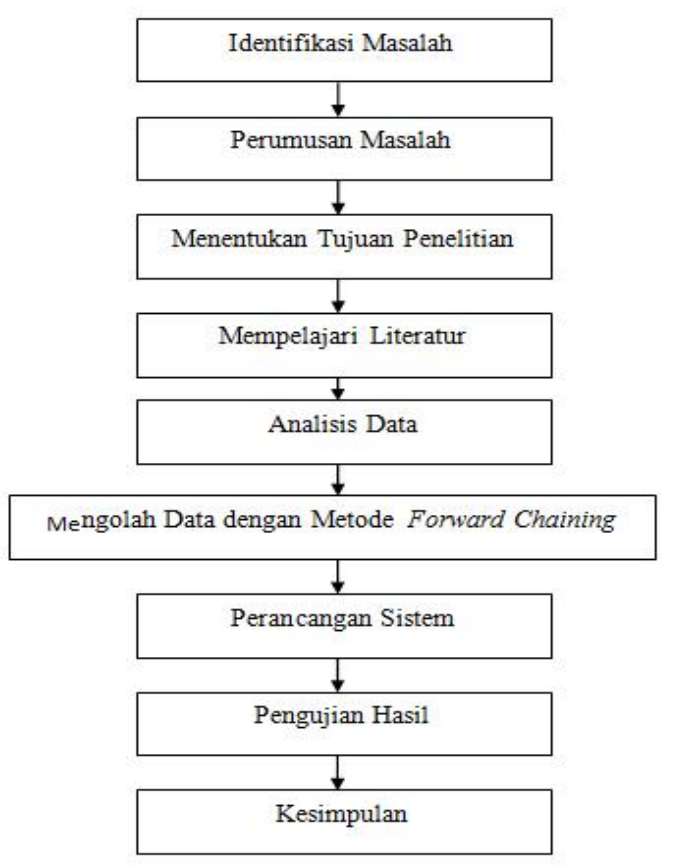

\section{Gambar 1 Desain Penelitian}

Berikut ini adalah penjelasan dari desain penelitian yang ada pada gambar 3.1 di atas: (1) Identifikasi Masalah: Didalam tahap ini penelitian diawali dengan melakukan studi pendahuluan untuk mengidentifikasi permasalahan yang berkaitan dengan topik penelitian agar peneliti mendapatkan apa yang sesungguhnya menjadi masalah untuk dipecahkan. (2) Perumusan Masalah: Didalam tahap ini peneliti merumuskan masalah yang telah didapatkan agar masalah tersebut dapat dijawab dengan baik melalui penelitian. (3) Menentukan Tujuan Penelitian: Pada tahap ini tujuan penelitian yaitu mengetahui bagaimana sistem pakar mendeteksi tindak pidana cybercrime menggunakan metode forward chaining berbasis web. (4) Mempelajari Literatur: Pada tahap ini peneliti mencari dan mempelajari sumber-sumber pengetahuan berupa buku-buku teori, jurnal-jurnal penelitian, dan sumber pustaka otentik lainnya yang berkaitan dengan penelitian, seperti kecerdasan buatan, sistem pakar, tindak pidana cybercrime, php, mysql dan uml. (5) Analisi Data: Setelah data-data yang berkaitan dengan tindak pidana cybercrime didapatkan melalui wawancara dengan pakar tindak pidana cybercrime maupun melalui studi literatur yang berhubungan dengan tindak pidana cybercrime, kemudian peneliti menganalisa data-data yang dibutuhkan sistem pakar dan dikelompokkan agar lebih mudah melakukan proses pengolahan datanya. (6) Mengolah data dengan metode Forward Chanining: Setelah data-data yang telah dianalisa kemudian diolah menggunakan metode forward chaining untuk membuat kaidah (rule) yang akan digunakan saat sistem pakar melakukan penelusuran sebelum menyimpulkan hasil. (7) Perancangan Sistem: Pada tahap ini peneliti melakukan kegiatan perancangan mulai dari desain basis pengetahuan, desain uml, desain database, desain antar muka yang akan digunakan untuk mendeteksi tindak pidana cybercrime berdasarkan data yang ada. (8) Pengujian Hasil: Didalam tahap ini bertujuan untuk meminimalisir kesalahan dan memastikan keluaran yang dihasilkan sesuai dengan yang diinginkan. Sistem ini diuji dengan membandingkan hasil deteksi pakar dengan hasil deteksi sistem untuk melihat apakah sistem berjalan dengan baik. (9) Kesimpulan: Tahap terakhir dalam penelitian ini yaitu menyimpulkan hasil penelitian yang berisi jawaban terhadap rumusan masalah berdasarkan data-data yang ada. Peneliti juga memberikan saran yang penting untuk membantu dalam memecahkan permasalahan yang ada.

\section{Pengumpulan Data}

Pengumpulan data merupakan langkah yang dilakukan peneliti untuk mendapatkan data-data yang berkaitan dengan tindak pidana cybercrime untuk mendukung 
penelitian yang sedang dilakukan. Teknik pengumpulan data yang dilakukan dalam penelitian ini adalah: (1) Wawancara: Untuk mendapatkan data-data yang berkaitan dengan penelitian, peneliti melakukan wawancara langsung dengan Bapak Tyas Satria Manggala, S.STP yang bekerja sebagai Penata Tingkat I/III d, Kabid Penyelenggaraan E-Goverment di Kantor Dinas Komunikasi dan Informatika (Kominfo) lantai 7 (tujuh) Gedung Wali Kota Batam. (2) Studi Literatur: Peneliti melakukan studi literatur dengan mengumpulkan, membaca, dan memahami referensi teoritis yang berasal dari bukubuku, jurnal-jurnal penelitian dan sumber pustaka otentik lainnya yang berkaitan dengan penelitian.

\section{Operasional Variabel}

Variabel yang digunakan dalam penelitian ini adalah Tindak pidana cybercrime. Cybercrime didefinisikan sebagai perbuatan melanggar hukum yang memanfaatkan teknologi komputer yang berbasasis pada kecanggihan perkembangan teknologi internet. Terdapat beberapa bagian yang mempengaruhi tindak pidana cybercrime sekaligus menjadi indikator tindak pidana cybercrime.

\section{Metode Perancangan Sistem}

Peneliti telah melakukan proses akuisisi pengetahuan dengan mengumpulkan pengetahuan dan fakta dari sumber-sumber yang tersedia. Sumber pengetahuan dan fakta diperoleh melalui wawancara dengan pakar tindak pidana cybercrime dan studi literatur tentang materi yang berkaitan dengan tindak pidana cybercrime. Sumber pengetahuan dan fakta yang didapat berupa data-data yang berhubungan dengan tindak pidana cybercrime, sanksi-sanksi tindak pidana cybercrime berdasarkan Undang-undang Nomor 11 Tahun 2008 tentang Informasi dan Transaksi Elektronik.
Tabel 1 Tabel Kejahatan

Cybercrime

\begin{tabular}{|c|l|}
\hline $\begin{array}{c}\text { Kode } \\
\text { Kejahatan }\end{array}$ & \multicolumn{1}{|c|}{ Jenis Kejahatan } \\
\hline K01 & Kejahatan Asusila \\
\hline K02 & Kejahatan Perjudian \\
\hline K03 & $\begin{array}{l}\text { Kejahatan Penghinaan dan } \\
\text { Pencemaran Nama Baik }\end{array}$ \\
\hline K04 & $\begin{array}{l}\text { Kejahatan Pemerasan dan } \\
\text { Pengancaman }\end{array}$ \\
\hline K05 & $\begin{array}{l}\text { Kejahatan Penipuan dan } \\
\text { Berita Bohong }\end{array}$ \\
\hline K06 & $\begin{array}{l}\text { Kejahatan Berita Kebencian } \\
\text { dan Permusuhan }\end{array}$ \\
\hline K07 & $\begin{array}{l}\text { Kejahatan } \\
\text { Kekerasan dan Menakut- } \\
\text { nakuti }\end{array}$ \\
\hline K08 & $\begin{array}{l}\text { Kejahatan Akses Komputer } \\
\text { Orang Tanpa Izin }\end{array}$ \\
\hline K09 & Kejahatan Penyadapan \\
\hline K10 & Kejahatan Cracker \\
\hline K11 & Kejahatan Hacker \\
\hline K12 & Kejahatan Abuse \\
\hline K13 & Kejahatan Pemalsuan Data \\
\hline
\end{tabular}

Sumber:Data Penelitian (2016)

Tabel 2 Tabel Ciri-ciri Kejahatan Cybercrime

\begin{tabular}{|c|l|}
\hline $\begin{array}{c}\text { Kode Ciri-ciri } \\
\text { Kejahatan }\end{array}$ & \multicolumn{1}{|c|}{ Ciri-ciri Kejahatan } \\
\hline CK01 & $\begin{array}{l}\text { Pelaku melakukan tindak } \\
\text { pidana cybercrime } \\
\text { kesusilaan }\end{array}$ \\
\hline CK02 & $\begin{array}{l}\text { Pelaku menyebarkan video } \\
\text { porno seseorang ke dunia } \\
\text { maya }\end{array}$ \\
\hline CK03 & $\begin{array}{l}\text { Membuat video porno } \\
\text { seseorang itu dapat di akses } \\
\text { oleh publik }\end{array}$ \\
\hline CK04 & $\begin{array}{l}\text { Pelaku melakukan aktivitas } \\
\text { Perjudian }\end{array}$ \\
\hline CK05 & $\begin{array}{l}\text { Pelaku melakukan aktivitas } \\
\text { perjudian secara online } \\
\text { disitus web }\end{array}$ \\
\hline CK06 & $\begin{array}{l}\text { Pelaku mengirim berupa } \\
\text { komentar dengan unsur } \\
\text { penghinaan ke pengguna } \\
\text { lain di sosial media }\end{array}$ \\
\hline
\end{tabular}


Penelitian Bidang Komputer Sains dan Pendidikan Informatika V3.i2(197-210)

\begin{tabular}{|c|c|}
\hline CK07 & $\begin{array}{l}\text { Pelaku mempublikasikan } \\
\text { identitas seseorang yang } \\
\text { bersifat fitnah di dunia } \\
\text { maya }\end{array}$ \\
\hline CK08 & $\begin{array}{l}\text { Pelaku mengirim pesan } \\
\text { yang berisi pemerasan atau } \\
\text { pengancaman terhadap } \\
\text { pihak tertentu di dunia } \\
\text { maya }\end{array}$ \\
\hline CK09 & $\begin{array}{l}\text { Pelaku meminta sejumlah } \\
\text { uang dan mengancam } \\
\text { menyebarkan photo vulgar } \\
\text { seseorang }\end{array}$ \\
\hline CK10 & $\begin{array}{l}\text { Pelaku menyebarkan } \\
\text { informasi atau berita } \\
\text { bohong yang dapat } \\
\text { menyesatkan seseorang }\end{array}$ \\
\hline CK11 & $\begin{array}{l}\text { Pelaku melakukan tindak } \\
\text { penipuan yang dapat } \\
\text { merugikan seseorang dalam } \\
\text { transaksi jual beli online }\end{array}$ \\
\hline CK12 & $\begin{array}{l}\text { Pelaku mengirim informasi } \\
\text { yang dapat menyebabkan } \\
\text { permusuhan }\end{array}$ \\
\hline CK13 & 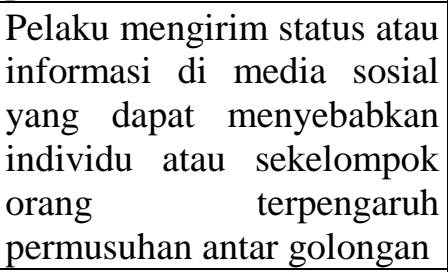 \\
\hline CK14 & $\begin{array}{l}\text { Pelaku mengancam dan } \\
\text { menakut-nakuti kepada } \\
\text { seseorang di sosial media }\end{array}$ \\
\hline CK15 & $\begin{array}{l}\text { Pelaku mengirim informasi } \\
\text { atau dokumen kepada } \\
\text { seseorang yang bersifat } \\
\text { teror yang dapat } \\
\text { meresahkan seseorang }\end{array}$ \\
\hline CK16 & $\begin{array}{lr}\text { Pelaku } & \text { mengakses } \\
\text { komputer atau } & \text { sistem } \\
\text { elektronik } & \text { seseorang } \\
\text { dengan cara apapun }\end{array}$ \\
\hline CK17 & $\begin{array}{l}\text { Pelaku mengakses sistem } \\
\text { seseorang untuk } \\
\text { memperoleh informasi yang } \\
\text { diinginkan }\end{array}$ \\
\hline CK18 & $\begin{array}{l}\text { Pelaku menerobos atau } \\
\text { menjebol } \\
\text { pengamanan } \\
\text { seseorang komputer } \\
\text { apapun }\end{array}$ \\
\hline
\end{tabular}

\begin{tabular}{|c|c|}
\hline CK19 & $\begin{array}{l}\text { Pelaku melakukan } \\
\text { penyadapan akses } \\
\text { komunikasi seseorang }\end{array}$ \\
\hline CK20 & $\begin{array}{lr}\text { Pelaku } & \text { melakukan } \\
\text { penyadapan } & \text { akses } \\
\text { komunikasi seseorang baik } \\
\text { yang tidak } & \text { menyebabkan } \\
\text { perubahan } & \text { maupun } \\
\text { menyebabkan } & \text { perubahan } \\
\text { atau penghentian informasi }\end{array}$ \\
\hline CK21 & $\begin{array}{l}\text { Pelaku memindahkan atau } \\
\text { mentransfer dokumen } \\
\text { elektronik kepada sistem } \\
\text { elektronik orang lain yang } \\
\text { tidak berhak dengan cara } \\
\text { apapun }\end{array}$ \\
\hline CK22 & $\begin{array}{lr}\text { Pelaku } & \text { merusak, } \\
\text { mengurangi } & \text { atau } \\
\text { menyembunyikan informasi } \\
\text { atau dokumen } & \text { elektronik } \\
\text { milik orang lain } & \\
\end{array}$ \\
\hline CK23 & $\begin{array}{l}\text { Pelaku mengirim software } \\
\text { atau virus sistem seseorang }\end{array}$ \\
\hline CK24 & $\begin{array}{l}\text { Pelaku melakukan tindakan } \\
\text { yang membuat } \\
\text { terganggunya sistem } \\
\text { seseorang agar tidak } \\
\text { bekerja sebagaimana mesti }\end{array}$ \\
\hline CK25 & $\begin{array}{lr}\text { Pelaku menyediakan } \\
\text { perangkat keras atau } \\
\text { perangkat lunak untuk } \\
\text { memfasilitasi kejahatan } \\
\text { cybercrime }\end{array}$ \\
\hline CK26 & $\begin{array}{l}\text { Pelaku menjual kata sandi } \\
\text { atau kode akses dengan } \\
\text { tujuan memfasilitasi } \\
\text { kejahatan cybercrime }\end{array}$ \\
\hline CK27 & $\begin{array}{l}\text { Pelaku melakukan } \\
\text { pemalsuan dokumen atau } \\
\text { informasi milik perusahaan } \\
\text { atau instansi dengan cara } \\
\text { apapun }\end{array}$ \\
\hline CK28 & $\begin{array}{l}\text { Pelaku memanipulasi data } \\
\text { tersebut sehingga seolah- } \\
\text { olah dianggap data yang } \\
\text { otentik }\end{array}$ \\
\hline
\end{tabular}

Sumber: Data Penelitian (2016)

Berdasarkan Tabel 1 dan Tabel 2, maka kaidah yang akan digunakan dalam 
sistem pakar dan Pohon Keputusannya adalah sebagai berikut:

\section{Perancangan Pohon Keputusan}

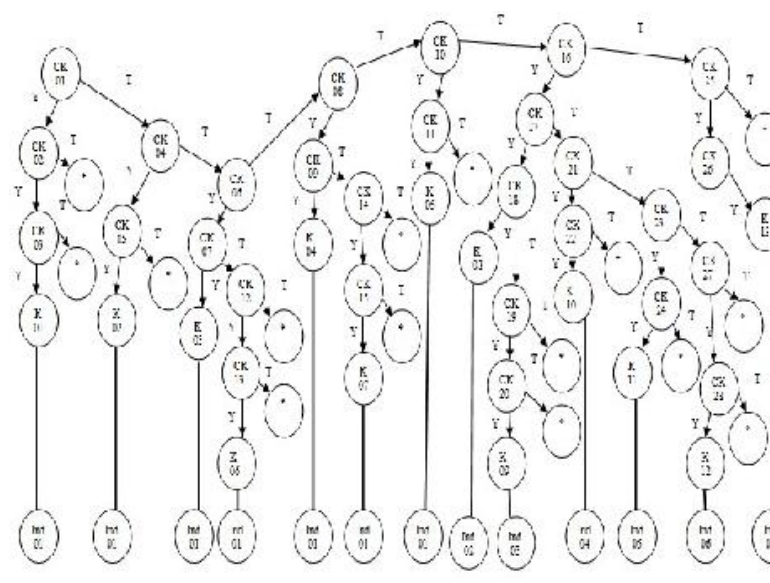

Gambar 2 Pohon Keputusan

Beerdasarkan gambar 3.2 diatas, Data ciri-ciri kasus ditentukan sebagai keadaan awal dalam sistem pakar ini saat melakukan penelusuran sebelum memperoleh keputusan atau kesimpulan. Proses penelusuran selanjutnya tergantung bagaimana jawaban yang diberikan pengguna. Jika pengguna memberikan jawaban "Benar", maka penelusuran menuju simpul kiri pada level berikutnya dan jika pengguna memberikan jawaban "Tidak", maka penelusuran menuju simpul kanan pada level berikunya, begitu seterusnya sampai penelusuran menemukan simpul " $\mathrm{K}$ (Kode Kejahatan)" atau simpul *. Simpul "K (Kode Kejahatan)" berasosiasi dengan simpul "IND (Indikator)" yang berarti bahwa simpul "K

(Kode Kejahatan)" tersebut bagian dari "IND (Indikator)". Simpul * merupakan simpul yang berarti tidak menghasilkan kesimpulan tertentu.

\section{Struktur Kontrol (Mesin Inferensi)}

Mesin inferensi dalam sistem pakar ini menggunakan metode penelusuran forward chaining. Langkah-langkah yang digunakan dalam proses penelusurannya adalah sebagai berikut: (1) Mengajukan pertanyaan tentang kasus-kasus tindak pidana cybercrime oleh pengguna internet (user). (2) Menyimpan sementara jawaban pengguna tentang kasuskasus tindak pidana cybercrime ke dalam memori sementara (3) Memeriksa gejalagejala yang ada dengan aturan yang telah dibuat, jika ada konklusi yang cocok maka simpan hasil kedalam memori tetap, jika belum memenuhi konklusi apapun, ulangi (4) Menampilkan hasil kasuskasus serta sanksi-sanksi tindak pidana cybercrime

\section{Perancangan Use Case}

Use case diagram menjelaskan aktoraktor yang terlibat dengan perangkat lunak yang dirancang untuk sistem pakar dalam penelitian ini beserta proses-proses di dalamnya. Berikut ini adalah gambaruser case diagramadmin dan user:

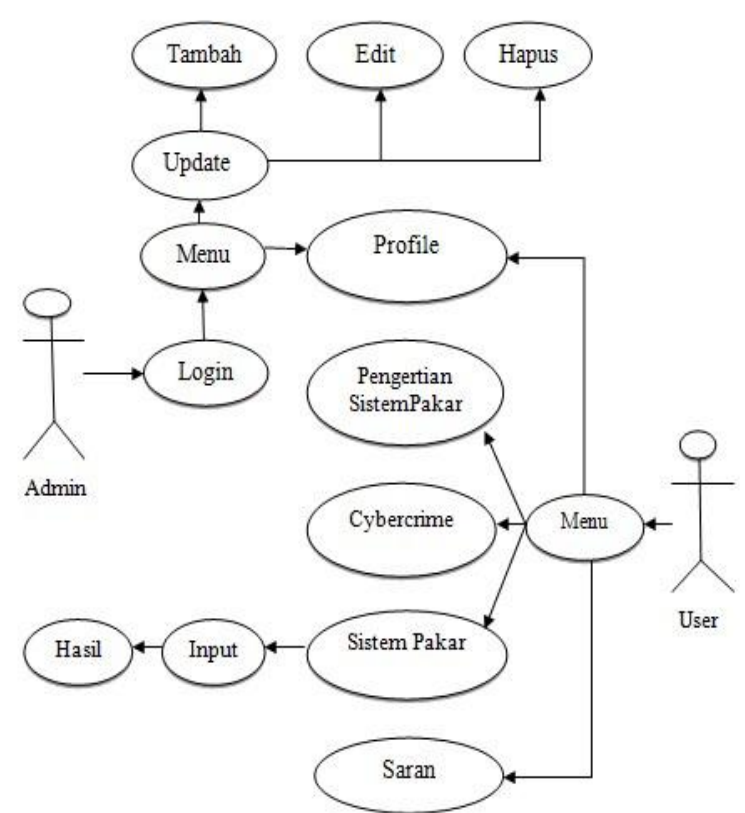

\section{Gambar 3 Diagram Use Case Admin dan User}

Berdasarkan gambar 3.3 di atas, berikut penjelasan mengenai aktor dan use case dalam perancangan sistem pakar mendeteksi tindak pidana cybercrime berbasis web: 


\section{Definisi aktor}

User merupakan orang yang akan menggunakan aplikasi sistem pakar ini. User dapat mengakses menu yang tersedia dalam aplikasi sistem pakar ini tanpa login terdahulu.

Sedangkan admin adalah orang yang mengelola sistem pakar ini.

\section{Definisi Use Case}

Merupakan penjelasan atau definisi mengenai aktor-aktor yang terlibat di dalam use case diagram admin dan user

Tabel 3 Definisi Use Case

\begin{tabular}{|c|c|}
\hline Use Case & Definisi \\
\hline Menu & $\begin{array}{l}\text { Merupakan proses yang } \\
\text { akan menampilkan } \\
\text { halaman utama saat } \\
\text { aplikasi dijalankan }\end{array}$ \\
\hline $\begin{array}{l}\text { Sistem Pakar dan } \\
\text { Cybercrime }\end{array}$ & $\begin{array}{l}\text { Merupakan proses yang } \\
\text { menampilkan halaman } \\
\text { atau beranda yang } \\
\text { menjelaskan pengertian } \\
\text { serta cirri-ciri dari } \\
\text { sistem pakar dan } \\
\text { cybercrime }\end{array}$ \\
\hline $\begin{array}{l}\text { Konsultasi Sistem } \\
\text { Pakar }\end{array}$ & $\begin{array}{l}\text { Merupakan proses yang } \\
\text { menampilkan untuk } \\
\text { konsultasi mengenai } \\
\text { tindak pidana } \\
\text { cybercrime dengan } \\
\text { menjawab } \\
\text { pertanyaanpertanyaan } \\
\text { yang telah disediakan }\end{array}$ \\
\hline Profil & $\begin{array}{l}\text { Merupakan proses yang } \\
\text { menampilkan profil dari } \\
\text { actor admin }\end{array}$ \\
\hline Saran & $\begin{array}{l}\text { Merupakan proses yang } \\
\text { menampilkan untuk } \\
\text { melakukan penilaian } \\
\text { atau juga memberikan } \\
\text { saran terhadap sistem } \\
\text { pakar ini }\end{array}$ \\
\hline Login & $\begin{array}{l}\text { Merupakan proses yang } \\
\text { menampilkan login } \\
\text { yang terdiri dari } \\
\text { username dan password } \\
\text { untuk masuk ke sistem }\end{array}$ \\
\hline
\end{tabular}

\begin{tabular}{|l|l|}
\hline & pakar ini \\
\hline Update & $\begin{array}{l}\text { Merupakan proses } \\
\text { yang menampilkan } \\
\text { untuk mengupdate data } \\
\text { seperti membuat data } \\
\text { baru, mengedit data } \\
\text { serta menghapus data } \\
\text { tentang tindak pidana } \\
\text { cybercrime yang telah } \\
\text { tersedia dalam sistem } \\
\text { pakar ini }\end{array}$ \\
\hline
\end{tabular}

Sumber: Data Penelitian (2016)

\section{Desain Database}

\section{Tabel Admin}

Tabel ini berfungsi untuk menyimpan data admin, berisikan username dan password untuk dapat masuk dan mengakses menu pada halaman admin.

Tabel 4 Tabel Admin

\begin{tabular}{|c|c|c|c|}
\hline No & Field & Type & Size \\
\hline 1 & Username & Varchar & 30 \\
\hline 2 & Password & Varchar & 30 \\
\hline
\end{tabular}

Sumber:Data Penelitian (2016)

\section{Tabel Konsultasi}

Tabel ini berfungsi untuk menyimpan data solusi dan pertanyaan yang akan ditampilkan oleh sistem pakar

Tabel 5 Tabel Konsultasi

\begin{tabular}{|c|c|c|c|}
\hline No & Field & Type & Size \\
\hline 1 & Id & Int & 11 \\
\hline 2 & solusi_pertanyaan & Varchar & 500 \\
\hline 3 & bila_benar & Int & 11 \\
\hline 4 & bila_salah & Int & 11 \\
\hline 5 & Mulai & char & 1 \\
\hline 6 & Selesai & char & 1 \\
\hline
\end{tabular}

Sumber: Data Penelitian (2016) 


\section{Jurnal Edik Informatika}

Penelitian Bidang Komputer Sains dan Pendidikan Informatika V3.i2(197-210)

\section{Tabel Comment}

Tabel ini berfungsi untuk menyimpan data komentar dan saran yang dibuat oleh user.

Tabel 3.6 Tabel Comment

\begin{tabular}{|c|c|c|c|}
\hline No & Field & Type & Size \\
\hline 1 & Nama & Varchar & 30 \\
\hline 2 & Komentar & Varchar & 500 \\
\hline 3 & Date & Datetime & \\
\hline
\end{tabular}

Sumber: Data Penelitian (2016)

\section{IV.HASIL PENELITIAN DAN PEMBAHASAN Menu Utama}

Menu Utama adalah menu yang muncul saat pertama kali pengguna mulai mengakses sistem. Menu Utama dapat diakses oleh siapa saja baik oleh pengguna biasa (user) maupun admin.

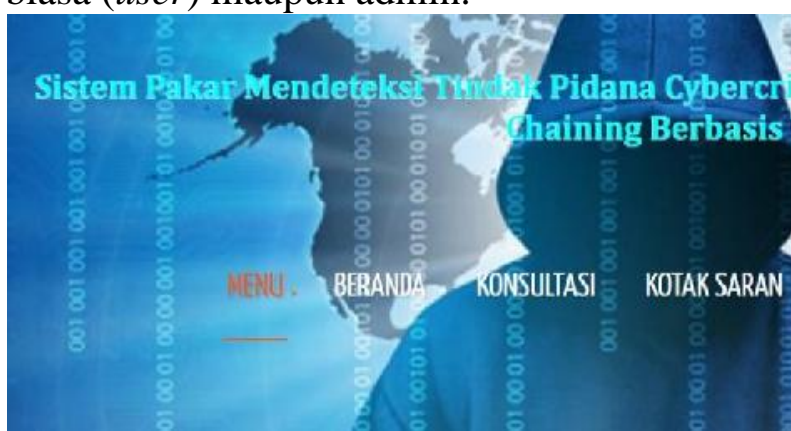

\section{Gambar 4 Menu Utama}

\section{Konsultasi Tindak Pidana Cybercrime}

Pada menu Konsultasi, pengguna akan diberikan pertanyaan-pertanyaan tentang tindak pidana kasus-kasus cybercrime ke pengguna. Pengguna diminta untuk menjawab pertanyaan dengan pilihan jawaban "Benar" atau "Tidak".

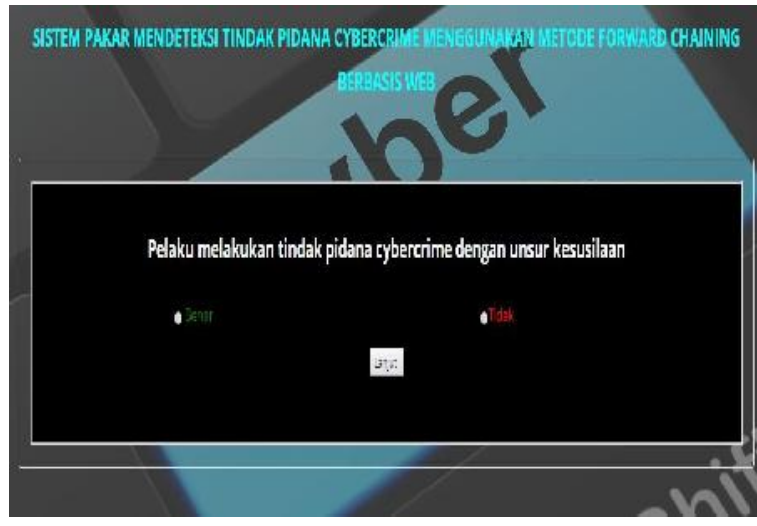

\section{Gambar 5 Konsultasi}

Setelah semua pertanyaan dari sistem telah dijawab oleh pengguna atau user, maka sistem akan melakukan proses penelusuran dan menampilkan hasilnya pada halaman Hasil Konsultasi.

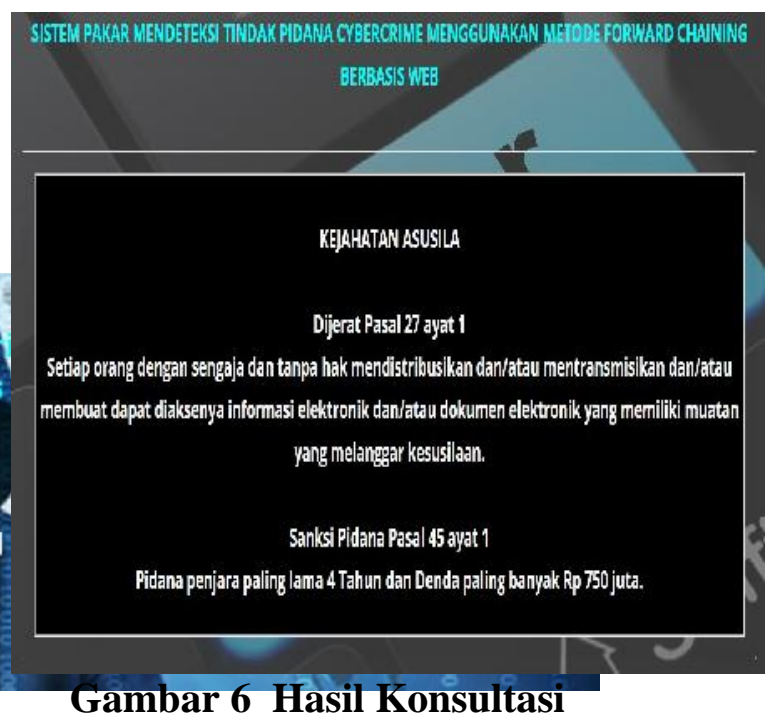

\section{Halaman Kotak Saran}

Halaman kotak saran berisi tentang kotak dan saran dari pengguna sistem pakar. 


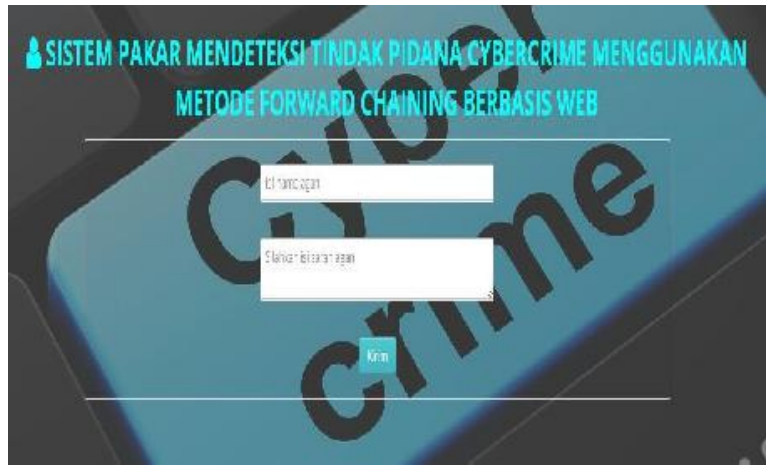

Gambar 7 Halaman Kotak Saran

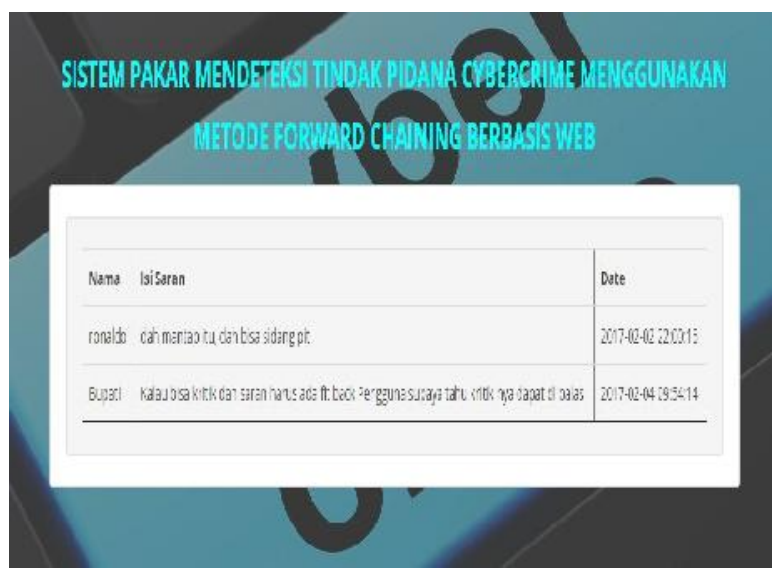

Gambar 8 Halaman Kotak Saran

\section{Halaman Login Admin}

Halaman Administrasi merupakan halaman yang digunakan oleh admin atau pakar untuk mengelola data-data yang digunakan dalam sistem pakar. Di halaman admin terdapat beberapa fitur beranda, data pasal dan kasus-kasus cybercrime, dan kotak saran.

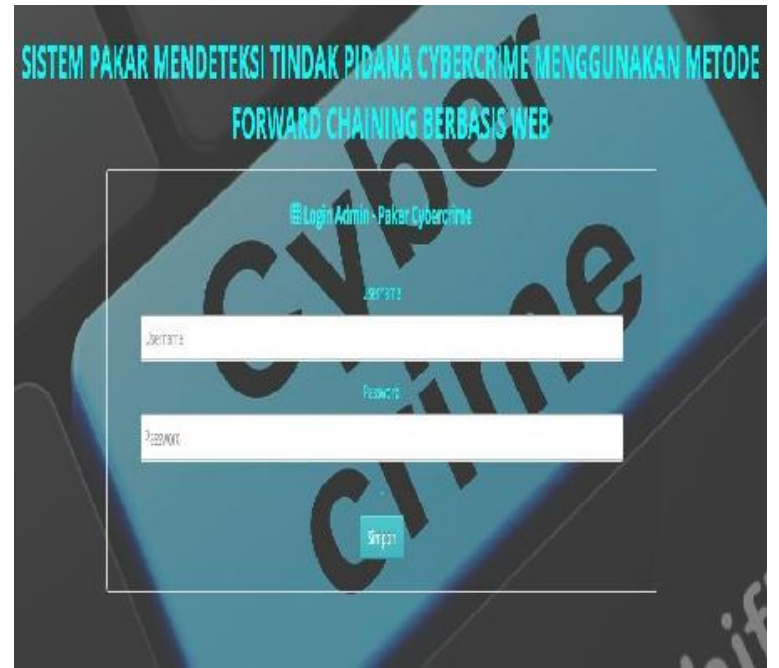

\section{Gambar 9 Halaman Login Admin}

\section{Basis Pengetahuan}

Menu ini berisi tabel yang menampilkan data-data pasal dan kasuskasus cybercrime yang telah dimasukkan oleh administrator atau pakar.

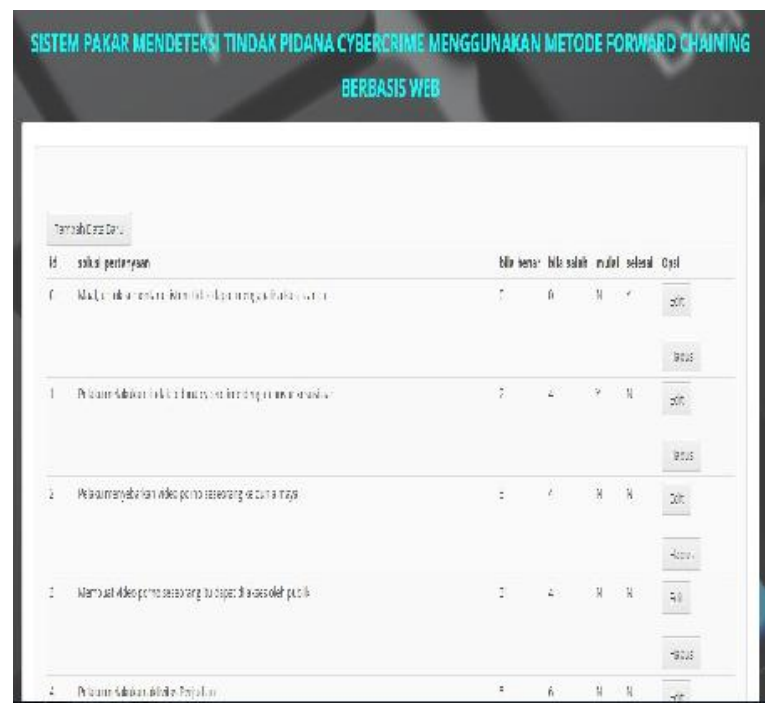

Gambar 10 Basis Pengetahuan

Dalam menu administrator tersebut, administrator atau pakar dapat menambahkan dan edit data-data pasal dan kasus-kasus cybercrime dengan menekan tombol menu Tambah Data Baru lalu dan Edit data. 


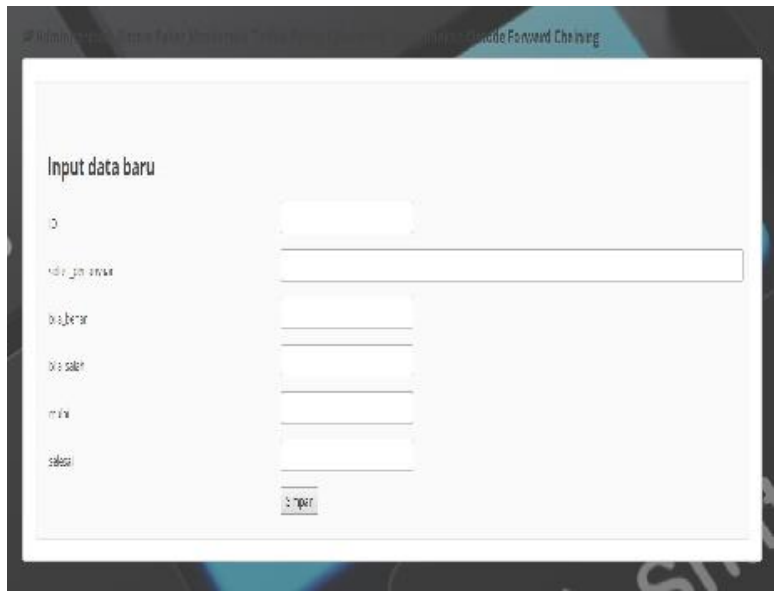

Gambar 11 Input Data Baru

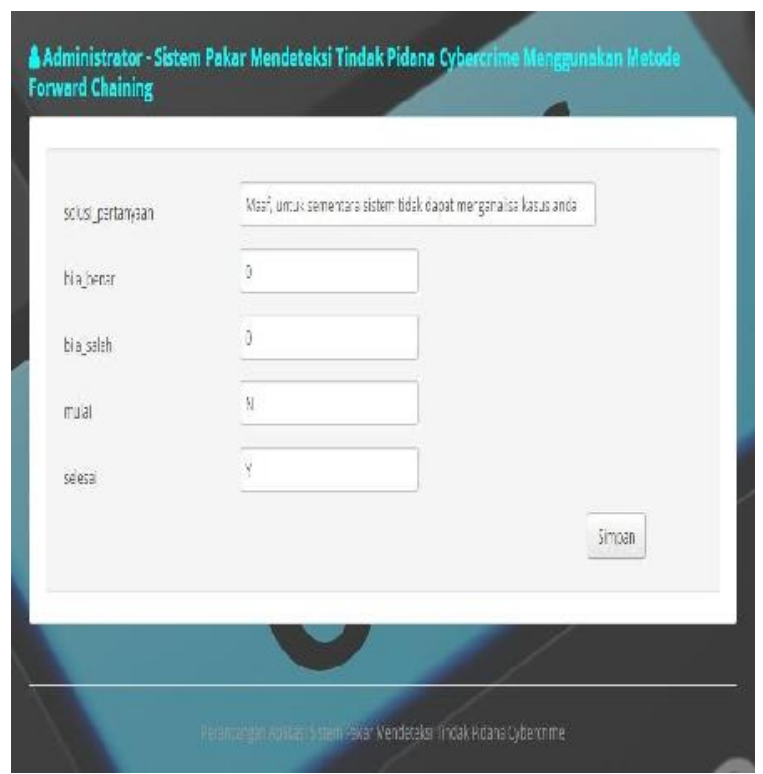

Gambar 12 Edit Data

\section{Pembahasan}

Pembahasan yang dijelaskan dalam penelitian ini adalah pengujian terhadap sistem pakar untuk membuktikan apakah sistem pakar telah berfungsi dengan baik pada saat digunakan untuk mendeteksi tindak pidana cybercrime.

\section{V.KESIMPULAN}

Berdasarkan penelitian ini, Sistem Pakar berbasis web menggunakan metode forward chaining untuk mendeteksi kejahatan tindak pidana cybercrime, dapat beberapa kesimpulan sebagai berikut: (1) Telah berhasil dibuat sistem pakar berbasis web menggunakan metode forward chaining yang mampu berperan sebagai seorang pakar untuk mendeteksi jenis-jenis kasus dan menentukan sanksi-sanksi kejahatan tindak pidana cybercrime. (2) Sistem pakar berbasis web menggunakan metode forward chaining ini memberikan informasi mengenai sanksi-sanksi tindak pidana cybercrime. (3) Data Sistem pakar ini dapat di update, ditambah, di edit, maupun dihapus oleh pakar apabila ditemukan atau perubahan data yang baru. (4) Output yang dihasilkansistem pakardari penelitian ini,berupa macam-macam kejahatan, pasal-pasal serta sanksi-sanksi tindak pidana cybercrime berdasarkan Undang-undang Republik Indonesia Nomor 11 Tahun 2008 tentang Informasi dan Transaksi Elektronik yang terbaru.

\section{DAFTAR PUSTAKA}

A.S., Rosa dan M. Shalahuddin. (2011). Rekayasa Perangkat Lunak: Terstruktur dan Berorientasi Objek. PENERBIT MODULA. Bandung.

Arifah, D.A (2011). Kasus Cybercrime di Indonesia.Jurnal Bisnis dan Ekonomi. Semarang. ISSN: 1412-3126, Vol 18 No 2: 185-195.

Hakim, L. (2014). Rahasia Inti Master PHP dan MySQLi. Edisi Pertama. LOKOMEDIA. Yogyakarta.

Hartati, S. dan Sari. I. (2008). Sistem Pakar dan Pengembangannya. Graha Ilmu. Yogyakarta

Hermawan, R (2013). Kesiapan Aparatur Pemerintah dalam Menghadapi Cybercrime di Indonesia. Jakarta. ISSN: 1979-276X, Faktor Exacta 6(1): 43-50.

Hidayatullah, P. dan J.K. Kawistara. (2015). Pemrograman Web. Cetakan Kedua. INFORMATIKA. Bandung.

Honggowibowo, A.S (2009). Sistem Pakar Diagnosa Penyakit Tanaman Padi Berbasis Web dengan Forward dan Backward Chaining. Jurnal 
TELKOMNIKA. Yogyakarta. ISSN: Sugiyono. (2012). Metode Penelitian 1693-6930, Vol 7 No 3:187-194. Kuantitatif, Kualitattif dan $R \& D$. Indriani, S (2008). Tinjauan Yuridis Alfabeta, Cetakan Ke-16. Bandung. Penegakan Hukum Terhadap Sutojo, T. (2011). Kecerdasan Buatan. Edisi Kejahatan Dunia Maya (Cybercrime). Pertama. ANDI OFFSET. Bandung. ISSN: 1979-0899XX, Vol 1 No 2: 60- Tentua, M.N (2010). Sistem Pakar Untuk 66 Identifikasi Kejahatan Dunia Juwairiah, dkk (2010). Sistem Pakar Berbasis Web Penentu Pasal Tindak Pidana Narkotika. Maya.Jurnal Dinamika Informatika. Yogyakarta. Volume 4, Nomor 1: 3544.

Seminar Nasional Informatika. Undang-undang Republik Indonesia Nomor Yogyakarta. ISSN: 1979-2328, D61D70. 11 Tahun 2008 Tentang Informasi dan Transaksi Elektronik. Hal: 1-29.

Prasetyo, T. (2010). Hukum Pidana. Widodo, (2009). Sistem Pemidanaan dalam RajaGrafindo Persada. Jakarta. Cybercrime. Laksbang Mediatama, Rosa, A.S. dan Shalahuddin, M. (2011). Cetakan Ke1. Yogyakarta.

Rekayasa Perangkat Lunak. Modula. Yusda, I.PP (2015). Analisis Terhadap Bandung.

Sudaryono. (2015). Metodologi Riset di Bidang TI; Panduan Praktis, Teori, dan Contoh Kasus. ANDI OFFSET. Yogyakarta. Cybercrime dalam Kaitannya dengan Asas Territorialitas. Jurnal TEKNOIF. Padang. ISSN: 2338-2724, Vol 3 No 1: $46-54$ 